Supplementary Information for

\title{
Discovery of a Broad-spectrum Fluorogenic Agonist for Strigolactone Receptors through
}

\section{Computational Approach}

Da-Wei Wang, ${ }^{\dagger}$ Shu-Yi Yu, ${ }^{\dagger}$ Zhi-Li Pang, ${ }^{\dagger}$ De-Jun Ma,${ }^{\dagger}$ Lu Liang,,${ }^{\dagger}$ Xia Wang, ${ }^{\dagger}$ Tao Wei,${ }^{\dagger}$ Huang-Ze Yang, ${ }^{\dagger}$ Yong-Qing Ma, ${ }^{\dagger}$ and Zhen $\mathrm{Xi}^{*}{ }^{\dagger}$

†State Key Laboratory of Elemento-Organic Chemistry, Department of Chemical Biology, National Pesticide Engineering Research Center, and Collaborative Innovation Center of Chemical Science and Engineering, College of Chemistry, Nankai University, Tianjin 300071, P. R. China.

The State Key Laboratory of Soil Erosion and Dryland Farming, Institute of Soil and Water Conservation, Northwest A\&F University, Yangling 712100, Shaanxi Province, China *Corresponding Author: E-mail: zhenxi@nankai.edu.cn (Z. Xi). 


\section{Contents}

Experimental Section S3

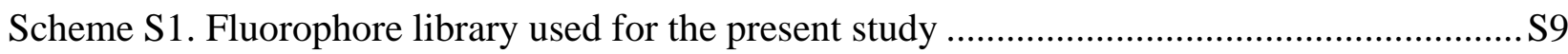

Table S1. The Consensus Docking Scores of the Top 9 Candidates .........................................S10

Table S2. Optimization of the Reaction Conditions for FP84 .................................................S11

Table S3. Calculated Quantum Yields of YLG and XLR in Reaction Systems .......................S12

Table S4. Calculated Binding Free Energies .............................................................................S13

Figure S1. Structures of some representative Strigolactones (SLs) .......................................S14

Figure S2. Model of SLs signaling mechanisms ................................................................. 14

Figure S3. Pharmacophore models analysis of the SL analogs and mimics .............................S15

Figure S4. Structural alignment of (+)-GR24, strigol, $(R, S)$-GC242, and $(R, S)$-EGO. .............S15

Figure S5. Chemical structures of nine hits by virtual screening ...........................................S16

Figure S6. The $\mathrm{pH}$ dependence of the maximum fluorescence intensity ..................................S16

Figure S7. Measurement of possible interference ...................................................................... 17

Figure S8. The absorption and fluorescence intensity of XLR ............................................ 17

Figure S9. Dose-dependent changes in the fluorescence of XLR ........................................... S18

Figure S10. Dose-dependent changes in the fluorescence of YLG .........................................S19

Figure S11. Lineweaver-Burk plots of XLR hydrolysis catalyzed by SL receptors...................S19

Figure S12. Dixon plot of the inhibitory kinetics of GR24 with YLG .................................. S20

Figure S13. Competitive inhibition of ShHTL7-mediated YLG ….........................................S20

Figure S14. Competitive inhibition of ShHTL7 and ShD14 by GR24 ...................................S21

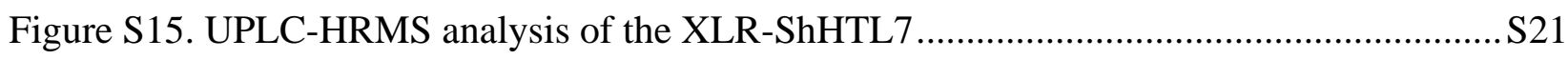

Figure S16. A proposed schematic diagram of ShHTL7-mediated XLR hydrolysis ................. S22

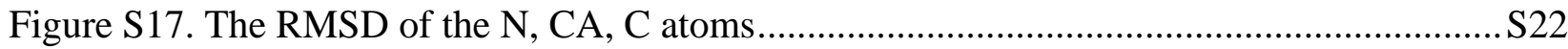

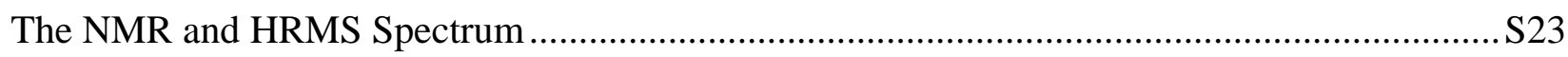

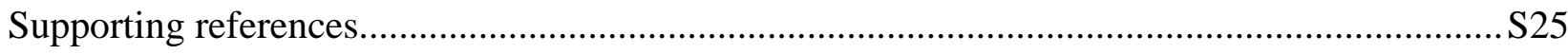




\section{Experimental Section}

Unless otherwise noted, all reagents were commercially available and used without further purification. Nuclear magnetic resonance (NMR) spectra were recorded with a Bruker AV 400 spectrometer at $400 \mathrm{MHz}\left({ }^{1} \mathrm{H}\right.$ NMR) and $101 \mathrm{MHz}\left({ }^{13} \mathrm{C}\right.$ NMR). Chemical shifts (values) were reported in ppm downfield from internal $\mathrm{Me}_{4} \mathrm{Si}(\delta 0.0 \mathrm{ppm})$. High-Resolution Mass Spectra (HRMS) were recorded on an IonSpec FT-ICR mass spectrometer with Electron Spray Ionization (ESI) resource. Thin Layer Chromatography (TLC) analyses were performed on the ZF-20D Cabinet UV analyzer (Yu Hua, Zhengzhou). Flash column chromatography was performed using 200-300 mesh of silica gel. 5-bromo-3-methylfuran-2(5H)-one (1) was prepared according to the reported procedure; ${ }^{1}$ 5-chloro-1,3-dimethyl-1,5-dihydro-2H-pyrrol-2-one (2) was prepared by referring to the literature, ${ }^{2}$ tert-butyl 5-bromo-3-methyl-2-oxo-2,5-dihydro-1H-pyrrole-1carboxylate (3a) and benzyl 5-bromo-3-methyl-2-oxo-2,5-dihydro-1H-pyrrole-1-carboxylate (3b) were prepared according to the reported method. ${ }^{3}$ Ultraviolet absorption spectra were recorded on a Cary 100 Bio UV-Visible spectrometer with a quartz cuvette. Fluorescence measurements were carried out on a Cary Eclipse fluorescence spectrophotometer with a quartz cuvette. The plasmids were obtained from Tsingke Biotechnology Co., Ltd. (Beijing, China) by the whole gene synthesis method.

Molecular Simulation Studies. AMBER 14 software package with ff14SB force fields was used to perform MD simulations of the $(R, S)$-XLR-receptor (ShHTL7, AtD14, and ShD14) systems. ${ }^{35}$ The parameters of ligands for MD simulations were prepared using the Antechamber program with the AMBER force fields (GAFF). The ligand-protein system was solvated with TIP3P water molecules in an $8.0 \AA$ A truncated octahedral box. $\mathrm{Na}^{+}$was used to neutralize the systems. Firstly, the energy of each of the systems was minimized by the conjugate gradient and the steepest descent methods. Then, the systems were gently annealed from 0 to $300 \mathrm{~K}$ in $50 \mathrm{ps}$ and followed by a 50 ps equilibrating calculation at $300 \mathrm{~K}$ and 1 atm using periodic boundary conditions in the NPT ensemble. ${ }^{36}$ Finally, each of the systems was performed $30 \mathrm{~ns}$ of MD simulation using the PMEMD module. The structures of the ligand-protein systems at the $30^{\text {th }} \mathrm{ns}$ of the MD simulation were analyzed by the CPPTRAJ module. The last $10 \mathrm{~ns}$ of MD trajectories were used for the energy decomposition analysis and binding free energies calculation.

The binding free energy for each of the minimized ligand-protein system was estimated using the molecular mechanics-Possion-Boltzmann surface area (MM-PBSA) method. The binding free energy with receptor, $\Delta G$ bind, was calculated according to the eq. 1 . 


$$
\Delta G_{\text {bind }}=G_{\text {complex }}-G_{\text {receptor }}-G_{\text {ligand }}
$$

Where, $G_{\text {complex }}$ is the free energy of receptor-ligand complex, $G_{\text {receptor }}$ is the free energy of unbound receptor, $G$ ligand is the free energy of ligand.

The binding free energy $\Delta G$ bind was calculated according to three items: MM gas-phase binding energy $\left(\Delta E_{\mathrm{MM}}\right)$, solvation free energy $\left(\Delta G_{\mathrm{sol}}\right)$, and entropic contribution $(-\mathrm{T} \Delta S)$, see eq. 2 . The binding energy ( $\left.\Delta E_{\text {bind }}\right)$ is the sum of gas-phase binding energy ( $\left.\Delta E_{\mathrm{MM}}\right)$ and solvation free energy $\left(\Delta G_{\text {sol }}\right)$, see eq3

$$
\Delta G_{\text {bind }}=\Delta E_{\mathrm{MM}}+\Delta G_{\mathrm{sol}}
$$

$\Delta E_{\mathrm{MM}}$ was calculated by eq. 3 , where, $\Delta E_{\text {ele }}$ and $\Delta E_{\mathrm{vdw}}$ are electrostatic and van der Waals (vdw), respectively. $\Delta G_{\text {sol }}$ was calculated by eq. 4 , where, $\Delta G_{\text {Рв }}$ is the electrostatic contribution to the solvation free energy and $\Delta G_{\mathrm{np}}$ is the nonelectrostatic contribution to the solvation free energy.

$$
\begin{aligned}
& \Delta E_{\mathrm{MM}}=\Delta E_{\mathrm{ele}}+\Delta E_{\mathrm{vdw}} \\
& \Delta G_{\mathrm{sol}}=\Delta G_{\mathrm{PB}}+\Delta G_{\mathrm{np}}
\end{aligned}
$$

The electrostatic contribution to the solvation free energy $\left(\Delta G_{\mathrm{PB}}\right)$ was calculated by PoissonBoltzmann (PB) method. $\Delta G_{\mathrm{np}}$ is the nonelectrostatic contribution to the solvation free energy determined as a function of the solvent-accessible surface area (SASA).

Quantum Yield Assay. The quantum yields of fluorescence for XLR and YLG were determined according to the previously methods ${ }^{4-5}$ using resorufin $(\Phi=0.75 \text { in } \mathrm{pH}=9.5 \text { aqueous solutions })^{6}$ and fluorescein $(\Phi=0.98,0.1 \mathrm{~mol} / \mathrm{L} \mathrm{NaOH})$ as a reference, respectively. The quantum yields for XLR and YLG and their corresponding fluorophore in the enzymatic reaction solution were tested with Abbe's refractometer and then calculated with the following equation.

$$
\phi_{s}=\frac{F_{s} \cdot A_{C}}{F_{c} \cdot A_{j}} \Phi_{c}
$$

Arabidopsis root hair experiments. The wild-type Arabidopsis thaliana (Colombia-0) was used in the root hair assay. Before experiments, the seeds of Arabidopsis were surface-sterilized. ${ }^{7}$ XLR and GR24 were dissolved in DMSO and prepared as the stock solution before use. The hot 1/2 MS liquid media (containing 1\% agar) containing XLR $(1 \mu \mathrm{M})$ or GR24 $(1 \mu \mathrm{M})$ were added to the Petri dishes (diameter $9 \mathrm{~cm}$ ) and then cooled to r.t., then the seeds of Arabidopsis were plated on the medium. Medium containing $0.1 \%$ DMSO was used as the control group. After chilling at $4{ }^{\circ} \mathrm{C}$ for 4 days, the dishes were placed vertically under a photoperiod of 16 -h-light $\left(125 \mu \mathrm{mol} \mathrm{m}^{-2} \mathrm{~s}^{-}\right.$ 
${ }^{1}$ )/8-h-dark at $21{ }^{\circ} \mathrm{C}$ for 15 days. OLYMPUS (U-HGLGPS) was used to observe the root hair. The experiments were performed with three biological repeats. The root hair of each root was measured by ImageJ (https://cnij.imjoy.io/); for per root, 16-20 root hairs were measured. For confocal microscopy on Arabidopsis root, the five days old wild-type Arabidopsis thaliana was incubated with XLR $(1 \mu \mathrm{M})$ in the PBS buffer $(1 \times, \mathrm{pH} 7.3)$ at $22{ }^{\circ} \mathrm{C}$ for one hour, then the fluorescence of the roots of Arabidopsis thaliana was visualized by OLYMPUS confocal microscopy at the red channel.

Arabidopsis Shoot Branching Inhibition Assay. Colombia-0 and max4-1 were used in this experiment, and the seeds were sterilized before use. The experiments were performed based on the protocols as described previously. ${ }^{7-8}$ Briefly, the seedlings were placed on the top of the cut black microcentrifuge tubes filled with $1 / 2 \mathrm{MS}$. The tubes were placed at $4{ }^{\circ} \mathrm{C}$ for 5 days and then moved to fluorescent white light (100-150 $\left.\mu \mathrm{mol} \mathrm{m} \mathrm{m}^{-2} \mathrm{~s}^{-1}\right)$ with 16-h light and 8-h dark at $20 \pm 1{ }^{\circ} \mathrm{C}$ for 7 days. The germinated seedlings were grown on hydroponic culture solutions (containing 2 $\mu \mathrm{M}$ of XLR or GR24), with the solution containing $0.1 \%$ DMSO as the negative control. The solutions were renewed every week. After four weeks, the numbers of rosette axillaries were analyzed. The experiments were performed in 3 biological repeats.

P. aegyptiaca seed germination assays. $P$. aegyptiaca seeds were harvested from Xinjiang province, China, in 2017. The seeds were surface-sterilized using $1 \% \mathrm{NaClO}$ solution for $2 \mathrm{~min}$, and then washed with distilled water six times. For seed germination assay, about 20 pieces of glass fiber-filter paper discs (13 mm diameter, Whatman GF/B) were placed separately on two layers of filter papers ( $9 \mathrm{~cm}$ diameter, Whatman) in the Petri dishes. $5 \mathrm{~mL}$ of distilled water was added to each petri dish to wet the papers. Approximately 50-80 sterilized seeds were spread onto each glass fiber-filter paper disc. After the seeds were conditioned in the dark at $25{ }^{\circ} \mathrm{C}$ for 4 days, ${ }^{9}$ the glass fiber-filter paper discs were blotted dry on filter papers $(9 \mathrm{~cm})$ and transferred to the wells of 24well cell culture plates. XLR and GR24 were dissolved in acetone and diluted to $10^{-5}-10^{-12} \mathrm{~mol} / \mathrm{L}$ with $\mathrm{H}_{2} \mathrm{O}\left(\mathrm{V}_{\mathrm{H} 2 \mathrm{O}} / \mathrm{V}_{\text {DMSO }}=999 / 1\right)$ just before use. ${ }^{10}$ Using $1 \%$ o DMSO solution as the negative control. $100 \mu \mathrm{L}$ of the test solution was added to each well of the plates. The plates were sealed and incubated in the dark at $25{ }^{\circ} \mathrm{C}$ for a week. The experiments were performed at least three biological repeats. The germinated seeds were observed by using an electronic magnifier at $20 \times$ magnification. EC50 values of XLR and GR24 were calculated using http://www.ic50.tk/index.html. 
Determination of detection limit of XLR and YLG. Based on the previous methods, ${ }^{11-12}$ all limit of detection experiments were carried out in a $200 \mu \mathrm{L}$ reaction solution $(1 \times \mathrm{PBS}, \mathrm{pH} 7.3)$ using a Cary Eclipse fluorescence spectrophotometer with a quartz cuvette. ${ }^{13}$ For XLR, a $200 \mu \mathrm{L}$ reaction solution containing XLR $(5 \mu \mathrm{M})$ and recombinant ShHTL7 (0-65 $\mu \mathrm{g} / \mathrm{mL})$, AtD14 (0-60 $\mu \mathrm{g} / \mathrm{mL})$, or ShD14 $(0-45 \mu \mathrm{g} / \mathrm{mL})$ were incubated at $25^{\circ} \mathrm{C}$ for $60 \mathrm{~min}$, then the fluorescence spectra of the systems were recorded at the wavelength of $585 \mathrm{~nm}\left(\lambda_{\mathrm{ex}}=550 \mathrm{~nm}\right)$. For YLG, a $200 \mu \mathrm{L}$ reaction solution containing YLG $(5 \mu \mathrm{M})$ and recombinant ShHTL7 (0-60 $\mu \mathrm{g} / \mathrm{mL})$, or AtD14 (0$60 \mu \mathrm{g} / \mathrm{mL}$ ) were incubated at $25^{\circ} \mathrm{C}$ for $60 \mathrm{~min}$, then the fluorescence spectra of the systems were recorded with wavelength of $520 \mathrm{~nm}\left(\lambda_{\mathrm{ex}}=480 \mathrm{~nm}\right)$. The detection limit for each SL receptor of XLR or YLG (not including ShD14) was determined by $3 \sigma / \mathrm{k}$, where $\sigma$ is the standard deviation of 6 blank samples, and $\mathrm{k}$ represents the slope of the regression lines. The experiments were performed with three repeats.

Hydrolysis assays with YLG. According to the reported methods, ${ }^{13}$ the competitive inhibition of SL receptors (ShHTL7, AtD14) activity by GR24, XLR, or resorufin was performed by using YLG as the substrate with the total reaction volume of $100 \mu \mathrm{L}$ in 96 -well black microplate at 25 ${ }^{\circ} \mathrm{C}$. Briefly, YLG $(3 \mu \mathrm{M})$ and ShHTL7 $(50 \mu \mathrm{g} / \mathrm{mL})$ were coincubated with GR24 (0.006-10 $\left.\mu \mathrm{M}\right)$, XLR $(0.001-1000 \mu \mathrm{M})$, or resorufin $(0.001-1000 \mu \mathrm{M})$ in reaction buffer $(1 \times \mathrm{PBS}, \mathrm{pH} 7.3)$; YLG $(3 \mu \mathrm{M})$ and AtD14 $(40 \mu \mathrm{g} / \mathrm{mL})$ were coincubated with GR24 $(0.001-100 \mu \mathrm{M})$. The fluorescence change of each well was recorded at the wavelength of $520 \mathrm{~nm}\left(\lambda_{\mathrm{ex}}=480 \mathrm{~nm}\right)$. After subtracting the background hydrolysis, a linear fluorescence increase in a period of $8 \mathrm{~min}$ was used for further inspection. The $\mathrm{IC}_{50}$ values were obtained via fitting relative inhibition percentages with the varying concentrations of compounds using Origin 8.0 software. The experiments were performed at least three biological repeats.

Construction of Fluorophore Library. A library containing 100 fluorophores such as fluorescein, bodipy, naphthalimide, and coumarin derivatives was collected from previous reports. ${ }^{14-17}$ First, the structures of the reported probes were split into fluorophores and the side chains, and the fluorophores were used in the current study. Subsequently, the structures of a library of 100 fluorophores were constructed and optimized using SYBYL 6.9 (Tripos, Inc., St. Louis, MO). Because all of the fluorophores are derived from previous reports, the constitutive properties of these fragments should be suitable for future de novo design. The asterisk shows the linking point, and the structures of the fluorophores in the library are shown in Scheme S2. 


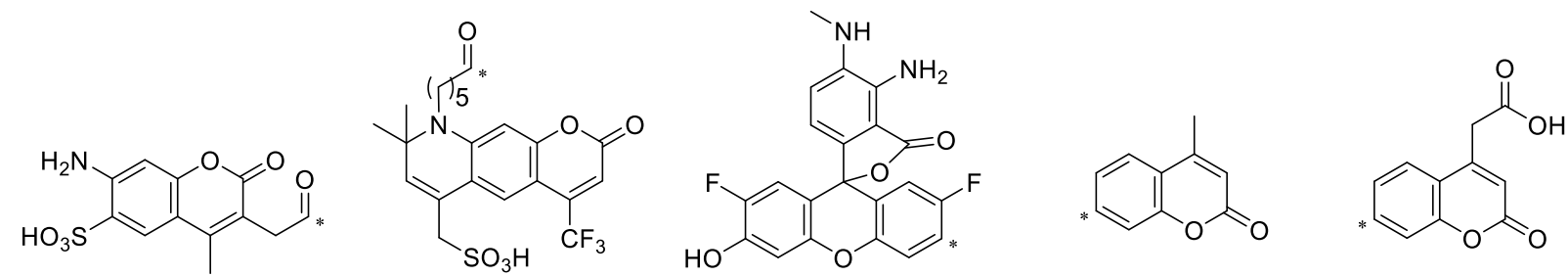

F1

F2

F3

F4

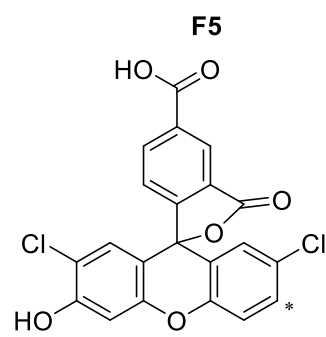

F6

F7

F8

F9

F10<smiles>O=C(O)c1ccc2c(c1)C1(OC2=O)c2ccc(Cl)cc2Oc2cc(O)c(Cl)cc21</smiles>

F11<smiles>O=C(O)c1ccc2c(c1)C(=O)OC21c2ccccc2Oc2c1ccc1cc(O)ccc21</smiles>

F15<smiles>O=C1Oc2ccccc2C2(O1)c1ccccc1Oc1cc(O)ccc12</smiles>

F20<smiles>O=C(O)c1ccc2c(c1)C(=O)OCC21c2ccc(O)cc2Oc2cc(O)ccc21</smiles>

F12<smiles>CC(=O)Oc1ccc2c(c1)Oc1cc(OC(C)=O)ccc1C21C(=O)OC(C)=C1C(=O)O</smiles>

F13<smiles>CC(=O)Oc1ccc2c(c1)Oc1cc(OC(C)=O)ccc1C21OC(=O)c2ccc(C(C)=O)cc21</smiles>

F14<smiles></smiles>

F16<smiles>CCCc1cc(=O)oc2ccccc12</smiles>

F22<smiles></smiles>

F23<smiles>Cc1c(CC(=O)O)c(=O)oc2ccccc12</smiles>

F24

F25

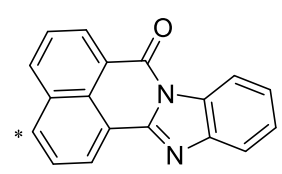

F26<smiles>Cc1ccc(-c2cnc(-c3ccncc3)o2)cc1</smiles>

F27<smiles>Cc1cc(=O)oc2c(F)c(F)ccc12</smiles>

F28<smiles>COc1ccc2cc(C(C)=O)c(=O)oc2c1</smiles>

F29

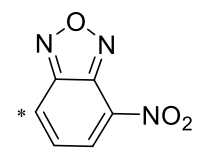

F30<smiles>O=C1OC2(c3cc(F)ccc3Oc3cc(O)c(F)cc32)c2ccccc21</smiles>

F31<smiles></smiles>

F32<smiles>O=C(O)c1cc2cc(F)cc(F)c2oc1=O</smiles>

F33 
(1)

F34

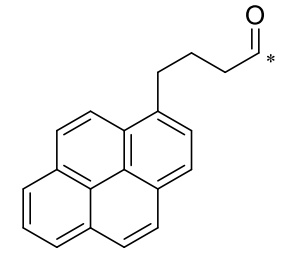

F35

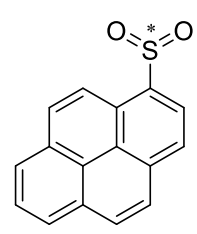

F36

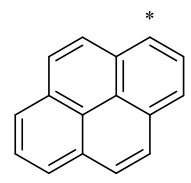

F37

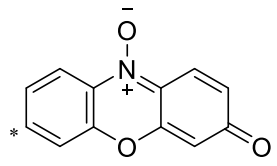

F38<smiles>O=S1(=O)c2ccccc2C2(Oc3ccc4cc(O)ccc4c3Oc3c2ccc2ccccc32)c2ccccc21</smiles>

F39<smiles>N#CC(C#N)=C1C=C(C=Cc2ccccc2)Oc2ccccc21</smiles>

F40
*

F41<smiles>CCOC(=O)c1ccccc1-c1c2ccc(=O)cc-2oc2ccccc12</smiles>

F42
$\left\langle=\mathrm{N}_{\mathrm{F}^{-B_{-}}-\mathrm{N}}\right.$

F43
$\mathrm{C}^{2}$

F45

F46
Cl

F47

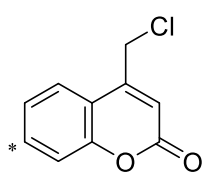

F48<smiles>Cc1c(F)cc2c(CCl)cc(=O)oc2c1F</smiles><smiles>CN1CCN(c2ccc([N+](=O)[O-])c3nonc23)CC1</smiles><smiles>c1ccc2sc(C3=NCCS3)nc2c1</smiles><smiles>O=C1CSC(c2nc3ccc(I)cc3s2)=N1</smiles>

F52<smiles>O=c1cc2oc3ccccc3nc-2c2ccccc12</smiles>

(1)

F54

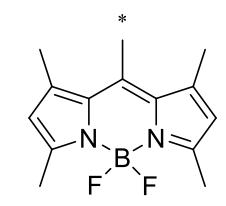

F55<smiles>COC(=O)c1ccccc1C1c2ccccc2Oc2cc(N)ccc21</smiles>

F56

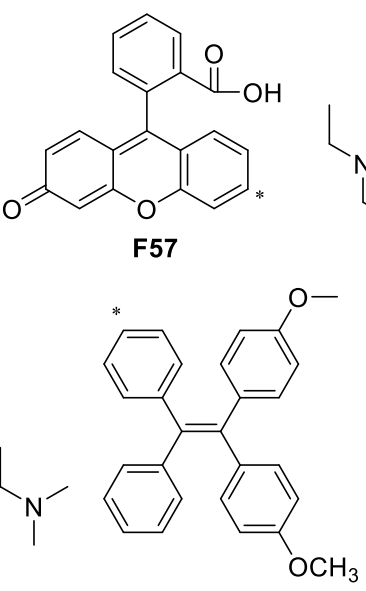

F62

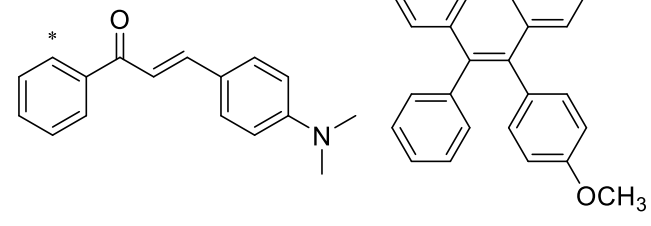

F61

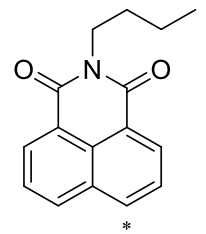

F67

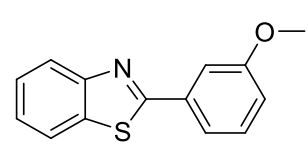

F68<smiles>O=C1C=CC2(C=C1)C1=C(Cl)C(=O)C(Cl)=CC1=Nc1ccccc12</smiles>

F69

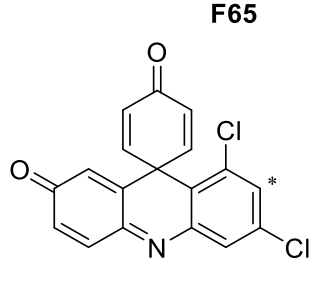

F70

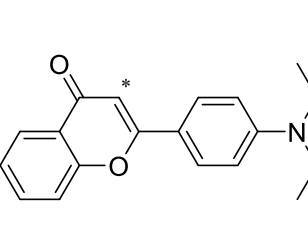

F71

F66

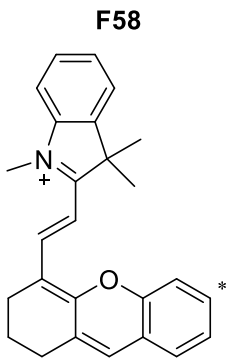

F63<smiles>N#C/C(=C\c1ccc(I)cc1)c1nc2ccccc2s1</smiles> 


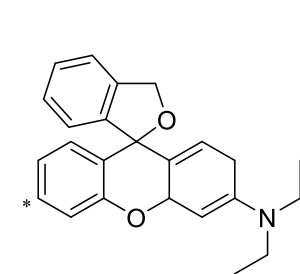

F74

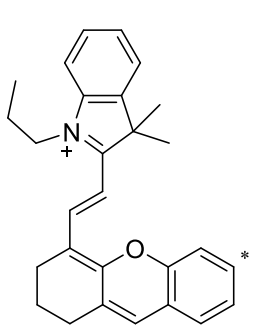

F79

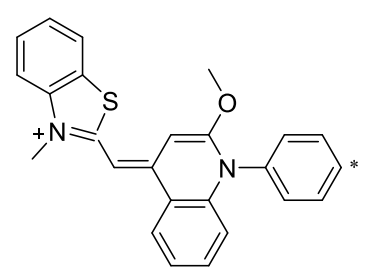

F75

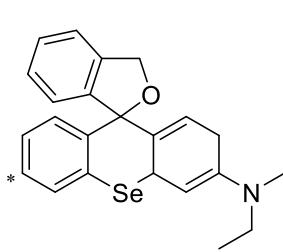

F76

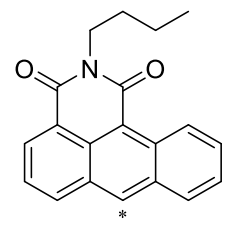

F77<smiles>N=c1cc2oc3ccccc3nc-2c2ccccc12</smiles>

F78<smiles>O=C1CCCC2Oc3cc(I)ccc3C=C12</smiles><smiles></smiles>

F80<smiles>CN(C)CCN1C(=O)c2cccc3cccc(c23)C1=O</smiles><smiles>CC1(C)CC(/C=C/c2ccccc2)=CC(=C(C#N)C#N)C1</smiles><smiles>N#Cc1ccc2ccccc2n1</smiles><smiles>CN(C)c1cccc2c(S(=O)(=O)O)cccc12</smiles>

F85<smiles>CC(=O)c1ccc2c(c1)C(C)(C)C1=C2C=C[C+]=C1</smiles>

F86

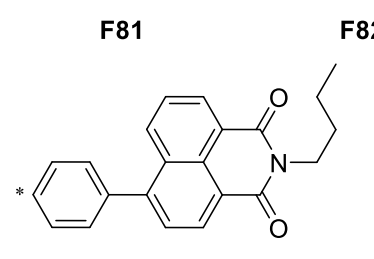

F87

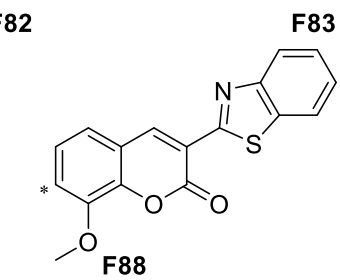<smiles>CN(C)CCN1C(=O)c2cccc3cccc(c23)C1=O</smiles><smiles>O=c1cc(C(F)(F)F)c2ccccc2o1</smiles><smiles>Cc1c(F)cc2c(C(F)(F)F)cc(=O)oc2c1F</smiles><smiles>CN1CCN(C(=O)c2cc3cc4c5c(c3oc2=O)CCCN5CCC4)CC1</smiles><smiles></smiles><smiles>CC1(C)C2=CC(=O)C=CC2=Nc2c(Cl)cc(Cl)cc21</smiles>

F90

F91

F92

F93<smiles>Cc1cc(S(=O)(=O)F)ccc1C1=C2C=CC(=O)C=C2[Si](C)(C)C2=C1C=C[C+]=C2</smiles>

F95

F96<smiles>O=c1oc2ccccc2cc1-c1nc2ccccc2s1</smiles>

F97<smiles>CN1CCN(S(=O)(=O)c2cccc3c(N(C)C)cccc23)CC1</smiles>

F98<smiles>CN(C)c1ccc(N=Nc2ccccc2)cc1</smiles>

F100

Scheme S1. Fluorophore library used for the present study. The asterisk means linking point. 
Table S1. The Consensus Docking Scores of the Top 9 Candidates

\begin{tabular}{|c|c|c|c|c|c|c|c|c|c|c|c|c|}
\hline \multirow{2}{*}{ Probe } & \multicolumn{4}{|c|}{ ShHTL7 } & \multicolumn{4}{|c|}{ AtD14 } & \multicolumn{4}{|c|}{ ShD14 } \\
\hline & probe & fluorophore & probe & fluorophore & probe & fluorophore & probe & fluorophore & probe & fluorophore & probe & fluorophore \\
\hline FP46 & -9.5 & -7.2 & -7.4 & -5.85 & -8.6 & -7.6 & -6.36 & -5.23 & -9.4 & -7.1 & -6.67 & -5.59 \\
\hline FP64 & -9.3 & -7.1 & -7.37 & -6 & -8.2 & -7.8 & -6.34 & -4.99 & -9.2 & -7.8 & -6.65 & -5.43 \\
\hline FP1 & -9.2 & -8.2 & -7.39 & -6.42 & -8.1 & -7.0 & -6.56 & -5.8 & -8.7 & -6.8 & -6.61 & -5.44 \\
\hline FP17 & -9.1 & -7.4 & -7.40 & -6.53 & -8.2 & -7.7 & -6.37 & -5.71 & -8.7 & -7.2 & -6.61 & -6.05 \\
\hline FP18 & -8.9 & -7.0 & -7.40 & -6.01 & -7.9 & -7.4 & -6.33 & -5.26 & -8.4 & -7.5 & -6.59 & -5.22 \\
\hline
\end{tabular}


Table S2. Optimization of the Reaction Conditions for FP84 ${ }^{a}$

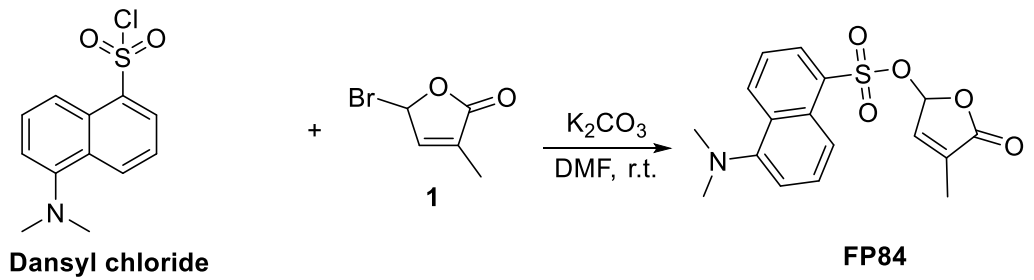

\begin{tabular}{clccccc}
\hline entry & base (equiv) & catalyst & solvent & temperature $\left({ }^{\circ} \mathrm{C}\right)$ & time (h) & yield $(\%)^{b}$ \\
\hline 1 & pyridine (2) & --- & $\mathrm{CH}_{2} \mathrm{Cl}_{2}$ & 0 -r.t. & $0.15-6$ & $\mathrm{NR}$ \\
2 & $\mathrm{Et}_{3} \mathrm{~N}(2)$ & --- & $\mathrm{CH}_{2} \mathrm{Cl}_{2}$ & 0 -r.t. & $0.15-6$ & $\mathrm{NR}$ \\
$3^{c}$ & DIPEA (2) & --- & $\mathrm{CH}_{2} \mathrm{Cl}_{2}$ & 0 -r.t. & $0.15-6$ & $\mathrm{NR}$ \\
$4^{c}$ & DIPEA (2) & DMAP (0.1) & $\mathrm{CH}_{2} \mathrm{Cl}_{2}$ & 0 -r.t. & $0.15-6$ & $\mathrm{NR}$ \\
5 & $\mathrm{~K}_{2} \mathrm{CO}_{3}(2)$ & --- & $\mathrm{CH}_{3} \mathrm{CN}$ & r.t. & 12 & $\mathrm{NR}$ \\
6 & $\mathrm{~K}_{2} \mathrm{CO}_{3}(2)$ & --- & $\mathrm{DMF}$ & r.t. & 12 & $\mathrm{NR}$
\end{tabular}

${ }^{a}$ Unless otherwise noted, the reactions were performed on a $0.74 \mathrm{mmol}$ scale of dansyl chloride and $0.86 \mathrm{mmol} \mathrm{scale}$ of D-OH (4). ${ }^{b}$ Isolated yield. 
Table S3. Calculated Quantum Yields of YLG and XLR in Reaction Systems ${ }^{a}$

\begin{tabular}{cccc}
\hline Fluorogenic substrate & QY & Reaction Systems & QY \\
\hline YLG & 0.12 & YLG + ShHTL7 & 0.42 \\
YLG & 0.12 & YLG + AtD14 & 0.41 \\
YLG & 0.12 & YLG + ShD14 & 0.17 \\
XLR & 0.055 & $\mathbf{X L R}+$ ShHTL7 & 0.67 \\
XLR & 0.055 & $\mathbf{X L R}+$ AtD14 & 0.66 \\
XLR & 0.055 & $\mathbf{X L R}+$ ShD14 & 0.31
\end{tabular}

${ }^{a}$ The measurements of YLG and XLR were performed in PBS buffer $(1 \times, \mathrm{pH} 7.3)$ at $25^{\circ} \mathrm{C}$. YLG was excited at $480 \mathrm{~nm}$, using fluorescein $(\Phi=0.98,0.1 \mathrm{~mol} / \mathrm{L} \mathrm{NaOH})$ as the standard. XLR was excited at $550 \mathrm{~nm}$, using resorufin $(\Phi=0.75 \mathrm{in} \mathrm{pH}=9.5$ aqueous solutions $)$ as the standard. 
Table S4. Calculated Binding Free Energies (kcal/mol) of $(R, S)$-XLR with ShHTL7, AtD14, and ShD14

\begin{tabular}{llllllll}
\hline receptor & compd & $\Delta E_{\text {ele }}$ & $\Delta E_{\mathrm{VDW}}$ & $\Delta E_{\mathrm{MM}}$ & $\Delta G_{\text {sol }}$ & $\Delta G_{\text {bind }^{a}}$ \\
\hline \multirow{2}{*}{ ShHTL7 } & $R$-XLR & -13.75 & -38.98 & -52.73 & 26.53 & -26.20 \\
& $S$-XLR & -5.26 & -36.40 & -41.66 & 19.76 & -21.90 \\
\hline \multirow{2}{*}{ AtD14 } & $R$-XLR & -11.46 & -35.29 & -46.75 & 19.57 & -27.18 \\
& $S$-XLR & -6.87 & -37.78 & -44.65 & 21.08 & -23.57 \\
\hline \multirow{2}{*}{ ShD14 } & $R$-XLR & -15.02 & -37.32 & -52.34 & 25.77 & -26.57 \\
& $S$-XLR & -16.01 & -39.33 & -55.34 & 30.02 & -25.32
\end{tabular}

${ }^{a} \Delta G_{\text {bind }}=\Delta E_{\text {ele }}+\Delta E_{\mathrm{vdw}}+\Delta G_{\text {sol. }}$. 


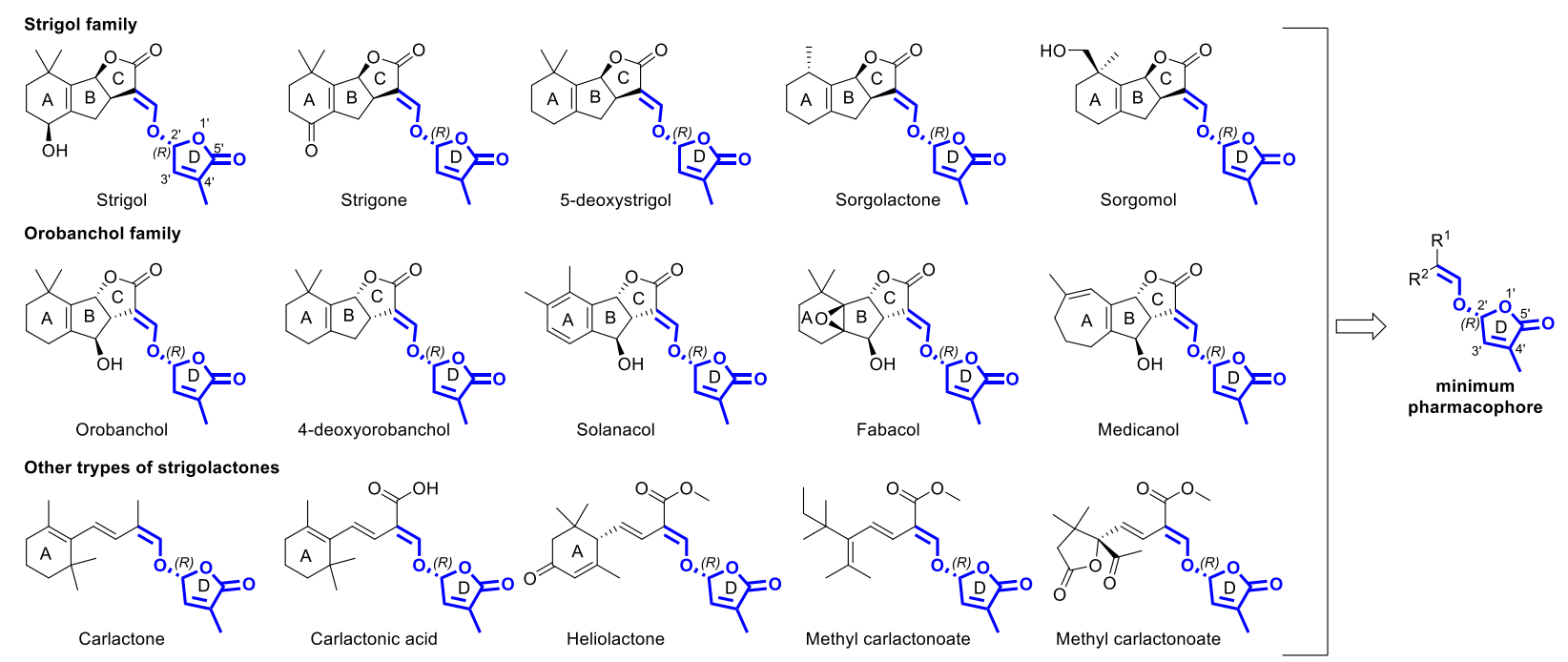

Figure S1. Structures of some representative Strigolactones (SLs) with ring lettering. ${ }^{18}$ The minimum common pharmacophore of the SLs is shown in bold blue lines.

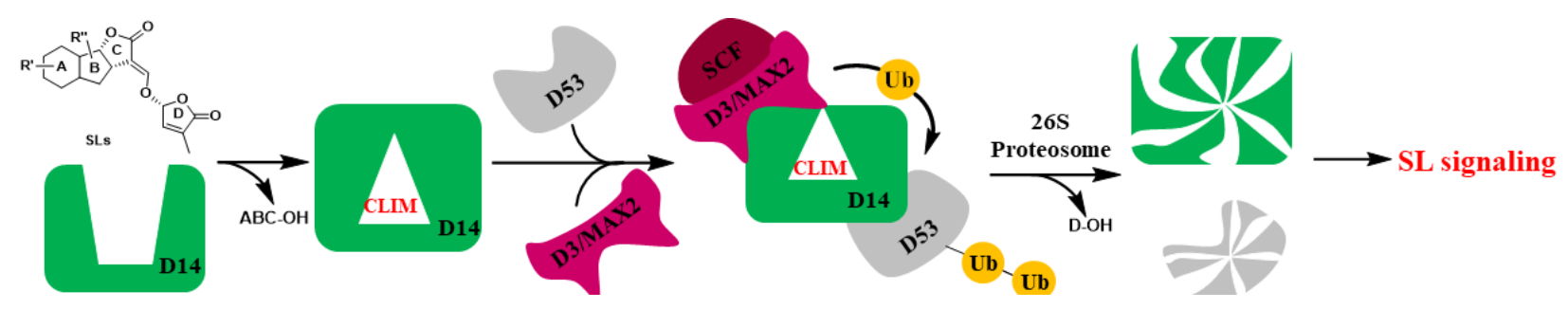

Figure S2. Model of SLs signaling mechanisms. In this model, SLs first bind to D14, then D14 hydrolyzes SLs to release ABC-OH moieties and make a covalently linked intermediate molecule (CLIM) modification on the His of the catalytic triad, which, in turn, inducing the conformation change of D14. Subsequently, D14 interacts with the D3/MAX2-based SCF complex and triggers the degradation of the complex. Finally, the D-OH is released, and signal transduction is initiated. 


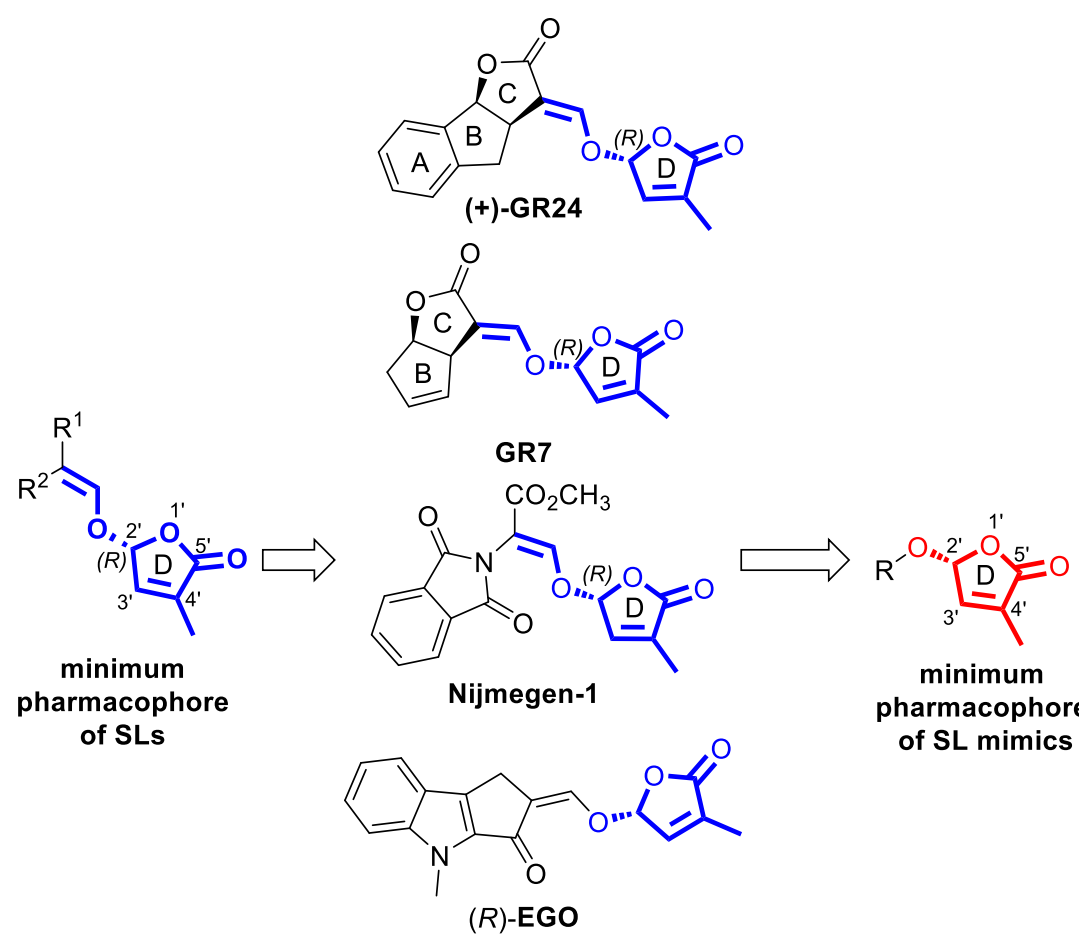

$S L$ analogues<smiles>CC1=CC(Oc2ccc(Br)cc2)OC1=O</smiles><smiles>CC1=CC(Oc2ccc(-c3ccccc3)cc2[N+](=O)[O-])OC1=O</smiles><smiles>CC1=CC(OC(=O)c2ccccc2)OC1=O</smiles><smiles>CC1=CC(OC(=O)Cc2ccccc2)OC1=O</smiles>

SL mimics

Figure S3. Pharmacophore models analysis of the SL analogs and mimics. The $2^{\prime} R$-configured enol ether butenolide function group was the minimum pharmacophore of SLs and SL analogs, the -O-D ring was the minimum pharmacophore of SL mimics.

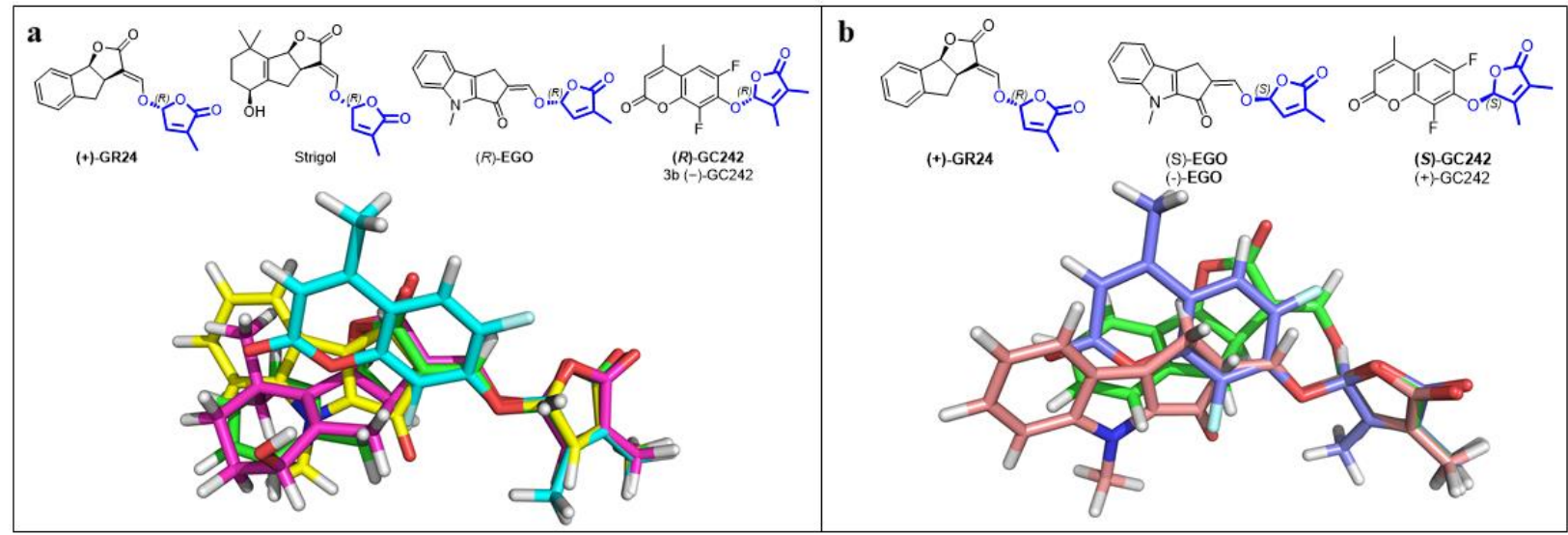

Figure S4. Structural alignment of (+)-GR24, strigol, $(R, S)$-GC242, and $(R, S)$-EGO. (a) 3D structural superimposition of (+)-GR24, strigol, $(R)-\mathrm{GC} 242$, and $(R)$-EGO. The structure of (+)GR24 is shown in green sticks, the structure of strigol is presented as magenta sticks, the structure of $(R)$-GC242 is depicted as cyan sticks, and the structure of $(R)$-EGO is illustrated as yellow sticks. (b) 3D structural superimposition of (+)-GR24, S-GC242, and S-EGO. The structure of (+)-GR24 is presented as green sticks, the structure of $S$-GC242 is shown as blue sticks, and the structure of $S$-EGO is depicted as salmon sticks. 

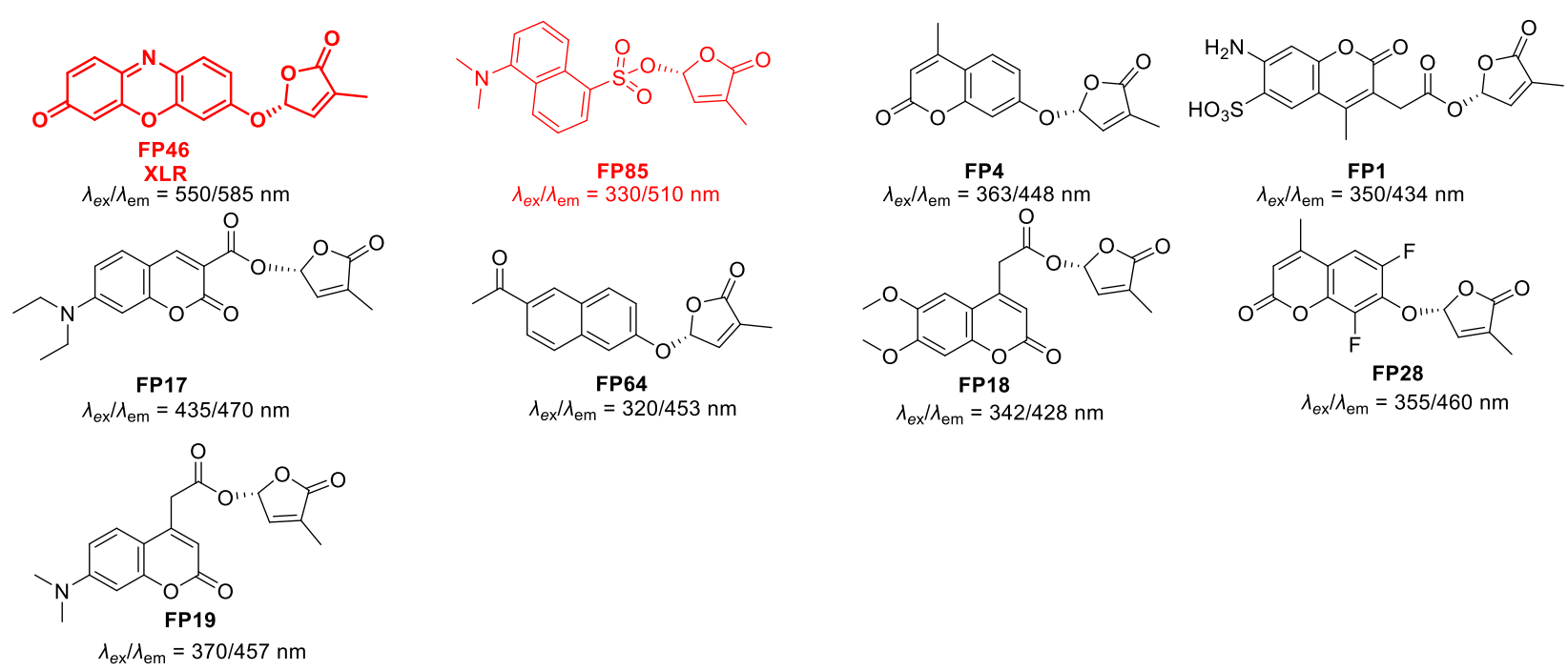

Figure S5. Chemical structures of 9 hits by virtual screening. The names of probes are composed of fluorescent probes (FP) and fluorophore numbers. The possible analytical wavelength of each probe is shown below their names.

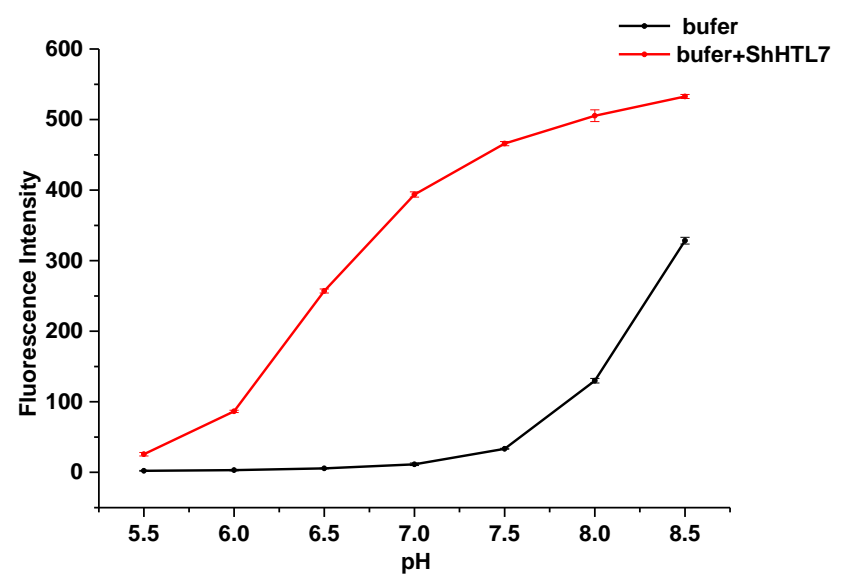

Figure S6. The $\mathrm{pH}$ dependence of the maximum fluorescence intensity for XLR with (red) and without (black) the addition of ShHTL7 in PBS buffer $(10 \mathrm{mM}, \mathrm{pH} 8.0)$ at $25^{\circ} \mathrm{C}$ for $60 \mathrm{~min}$. The results are expressed as the mean $\pm \operatorname{SD}(n=3)$. 

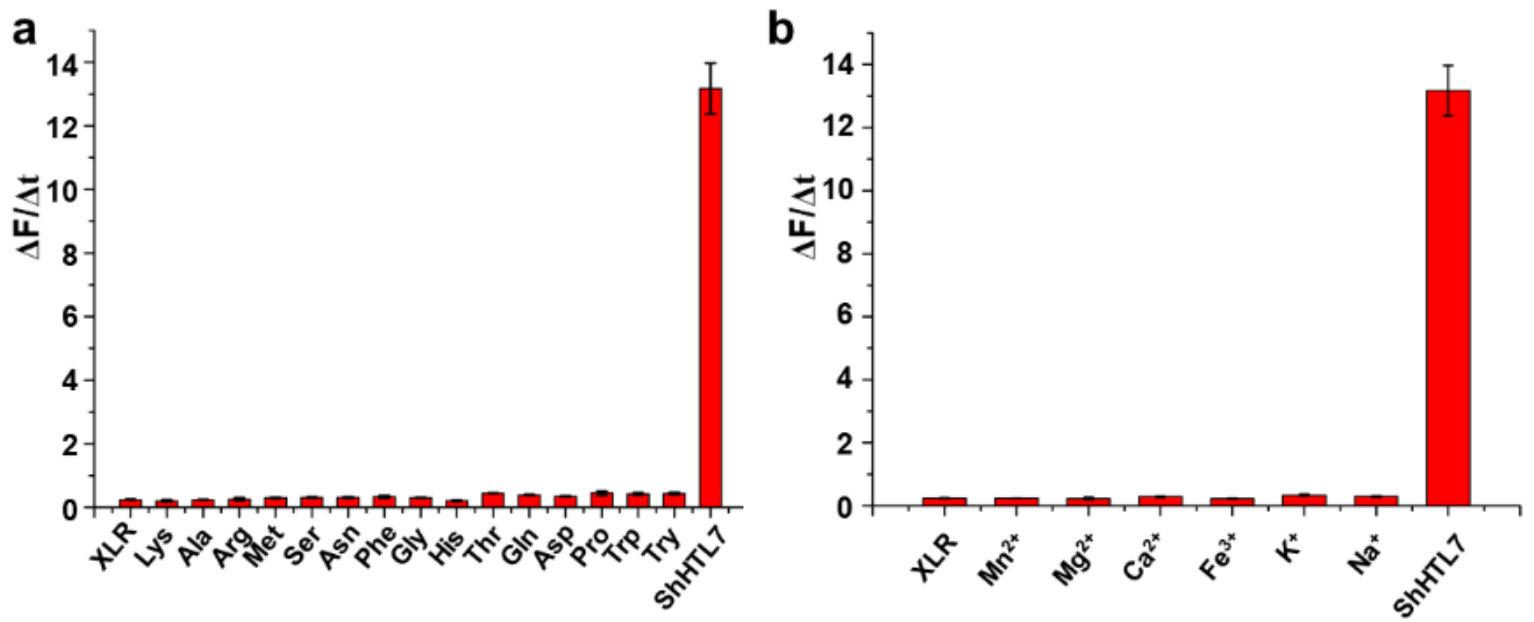

Figure S7. Measurement of possible interference on the signaling capability of XLR $(5 \mu \mathrm{M})$ by amino acids (Lys, Ala, Arg, Met, Ser, Asn, Phe, Gly, His, Thr, Gln, Asp, Pro, Trp, and Try) and metal ions $\left(\mathrm{Mn}^{2+}, \mathrm{Mg}^{2+}, \mathrm{Ca}^{2+}, \mathrm{Fe}^{3+}, \mathrm{K}^{+}, \mathrm{Na}^{+}\right)$. All the amino acids and metal ions except ShHTL7 $(87.5 \mu \mathrm{g} / \mathrm{mL})$ were tested at $100 \mathrm{mM}$. The results are expressed as the mean $\pm \mathrm{SD}(\mathrm{n}=3)$.
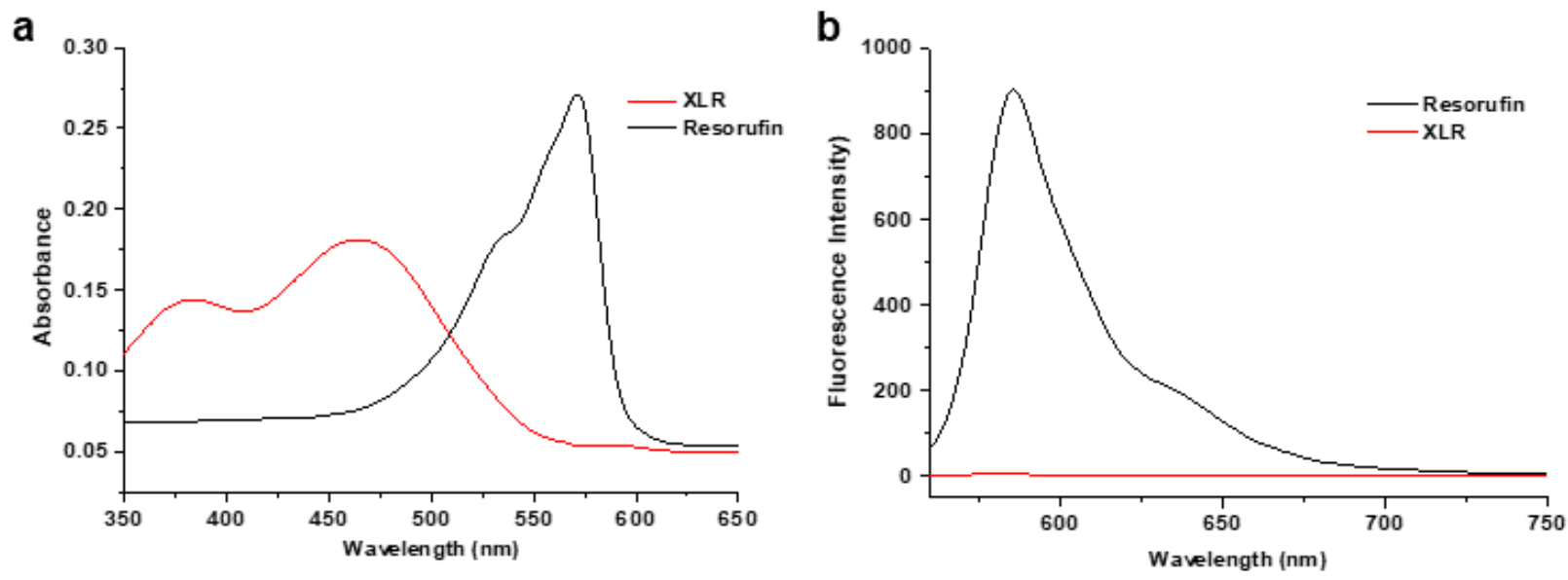

Figure S8. The absorption (a) and fluorescence intensity (b) of XLR $(5 \mu \mathrm{M})$ and resorufin $(5 \mu \mathrm{M})$ in reaction solution (PBS, $\mathrm{pH} 7.3)$ at $25^{\circ} \mathrm{C}$. The results are expressed as the mean $\pm \mathrm{SD}(\mathrm{n}=3)$. 

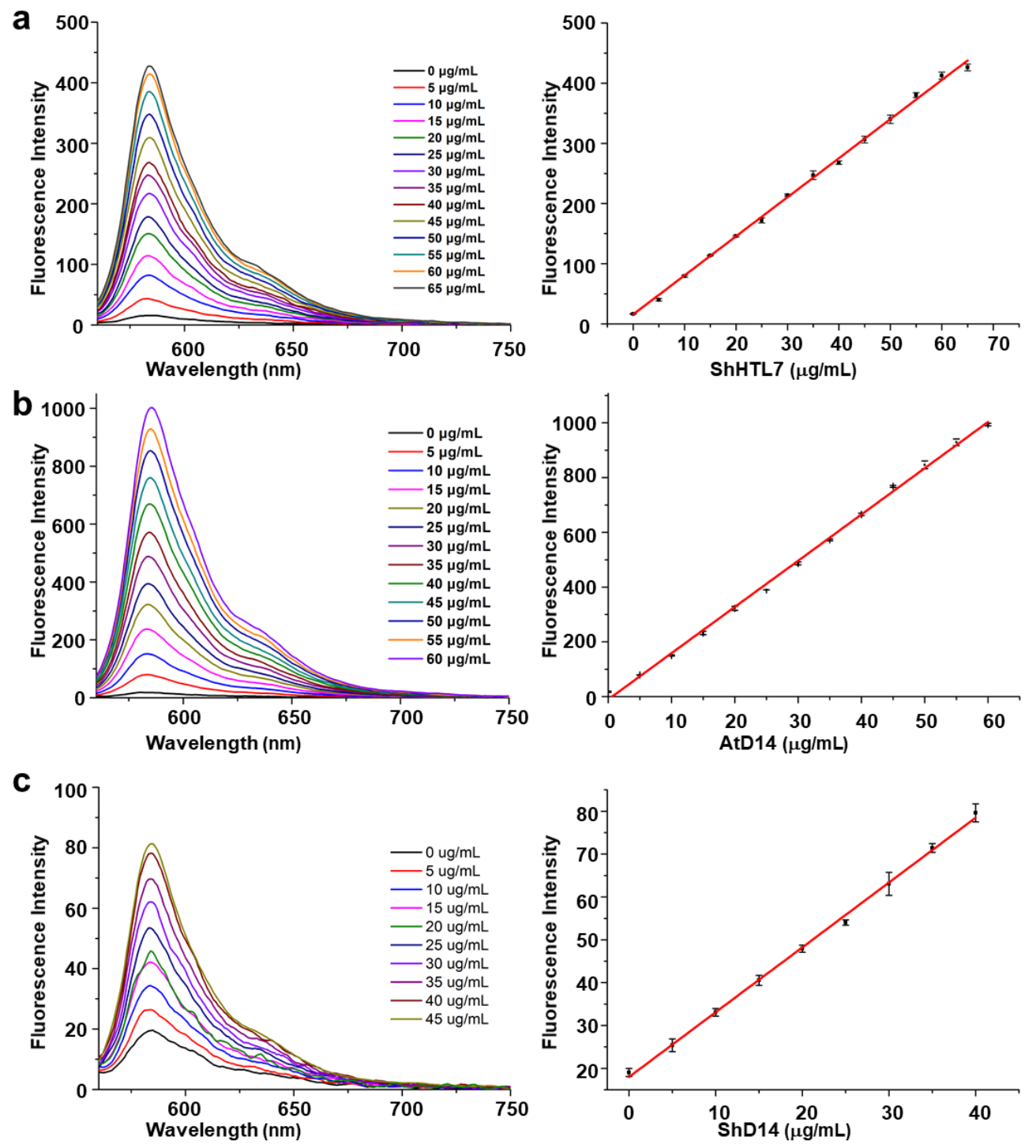

Figure S9. Dose-dependent changes in the fluorescence of XLR $(5 \mu \mathrm{M})$ at various concentrations of SL receptors in reaction buffer at $25^{\circ} \mathrm{C}$ for $60 \mathrm{~min}$. (a) Fluorescence change (left) and linear relationship (right) of XLR $(5 \mu \mathrm{M})$ at $0-65 \mu \mathrm{g} / \mathrm{mL}$ of ShHTL7 in the reaction buffer. (b) Fluorescence change (left) and linear relationship (right) of XLR $(5 \mu \mathrm{M})$ at 0-60 $\mu \mathrm{g} / \mathrm{mL}$ of AtD14 in the reaction buffer. (c) Fluorescence change (left) and linear relationship (right) of XLR $(5 \mu \mathrm{M})$ at $0-45 \mu \mathrm{g} / \mathrm{mL}$ of ShD14 in the reaction buffer. The data are shown as means $\pm \mathrm{SD}(\mathrm{n}=3)$. 

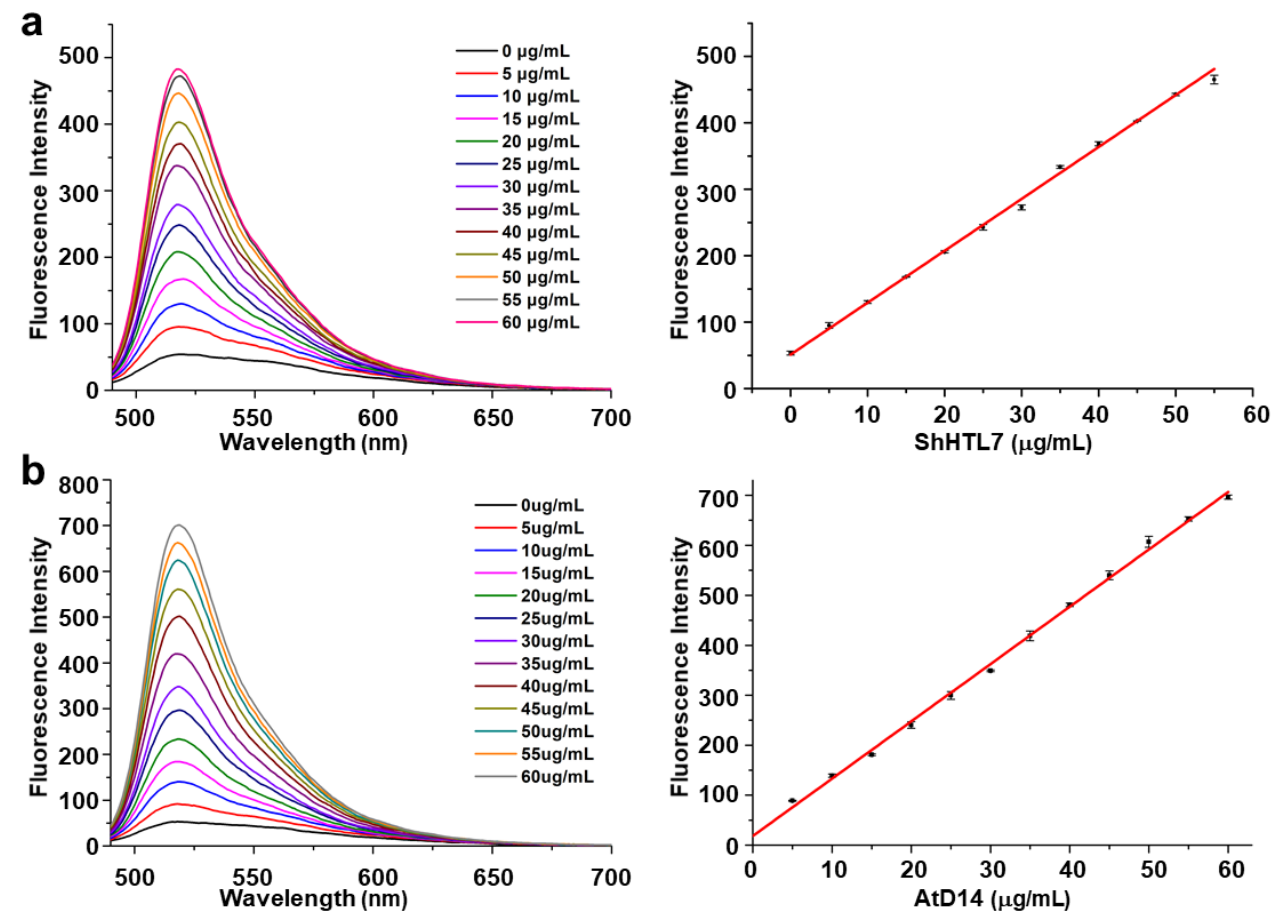

Figure S10. Dose-dependent changes in the fluorescence of YLG $(5 \mu \mathrm{M})$ at various concentrations of SL receptors in reaction buffer at $25{ }^{\circ} \mathrm{C}$ for $60 \mathrm{~min}$. (a) Fluorescence change (left) and linear relationship (right) of YLG $(5 \mu \mathrm{M})$ at $0-60 \mu \mathrm{g} / \mathrm{mL}$ of ShHTL7 in the reaction buffer. (b) Fluorescence change (left) and linear relationship (right) of YLG $(5 \mu \mathrm{M})$ at $0-60 \mu \mathrm{g} / \mathrm{mL}$ of AtD14 in the reaction buffer. The data are shown as means $\pm \operatorname{SD}(n=3)$.
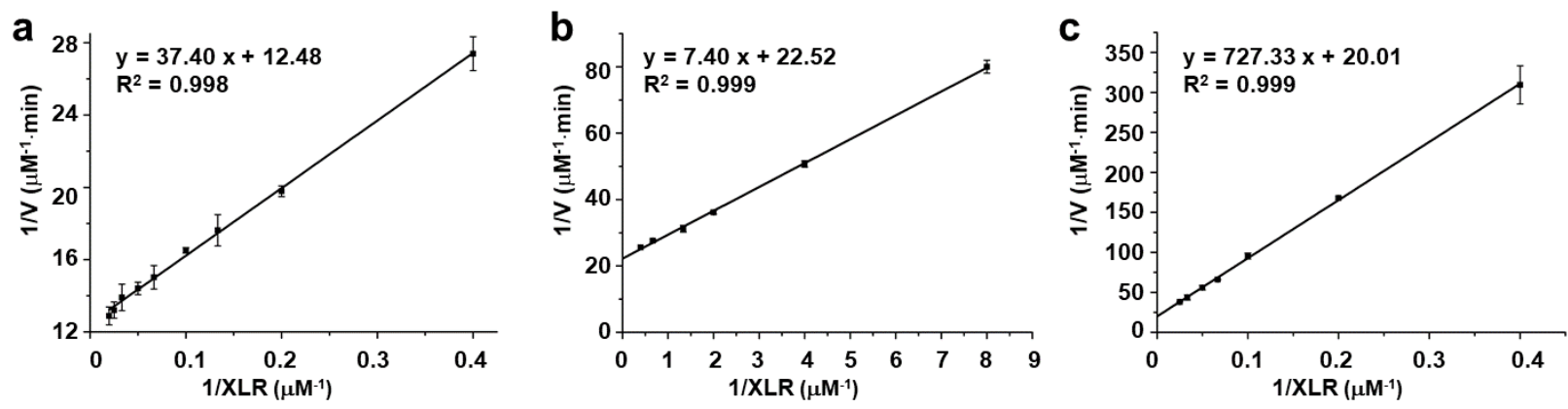

Figure S11. Lineweaver-Burk plots of XLR hydrolysis catalyzed by SL receptors in PBS buffer (10 mM, pH 7.3) using the fluorometric method. (a) ShHTL7 (44 $\mu \mathrm{g} / \mathrm{mL})$; (b) AtD14 $(35 \mu \mathrm{g} / \mathrm{mL})$; (c) $\mathrm{ShD} 14(40 \mu \mathrm{g} / \mathrm{mL})$. The data are shown as means $\pm \mathrm{SD}(\mathrm{n}=3)$. 


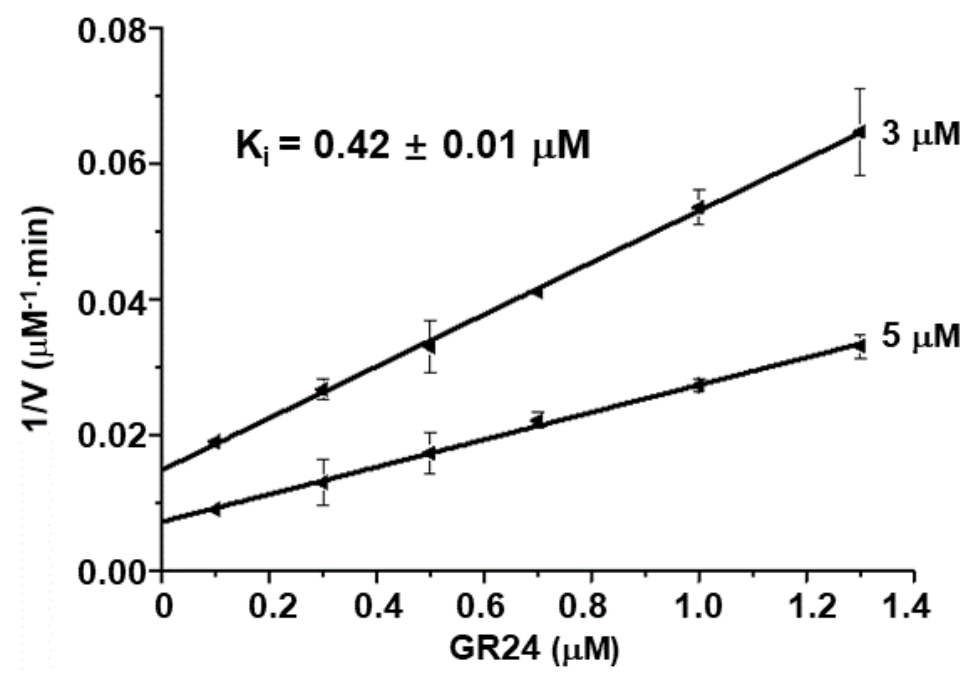

Figure S12. Dixon plot of the inhibitory kinetics of GR24 with YLG $(3 \mu \mathrm{M}$ and $5 \mu \mathrm{M})$ as the substrate of ShHTL7 $(50 \mu \mathrm{g} / \mathrm{mL})$ using the fluorometric method. Error bar indicates SD, $\mathrm{n}=3$.
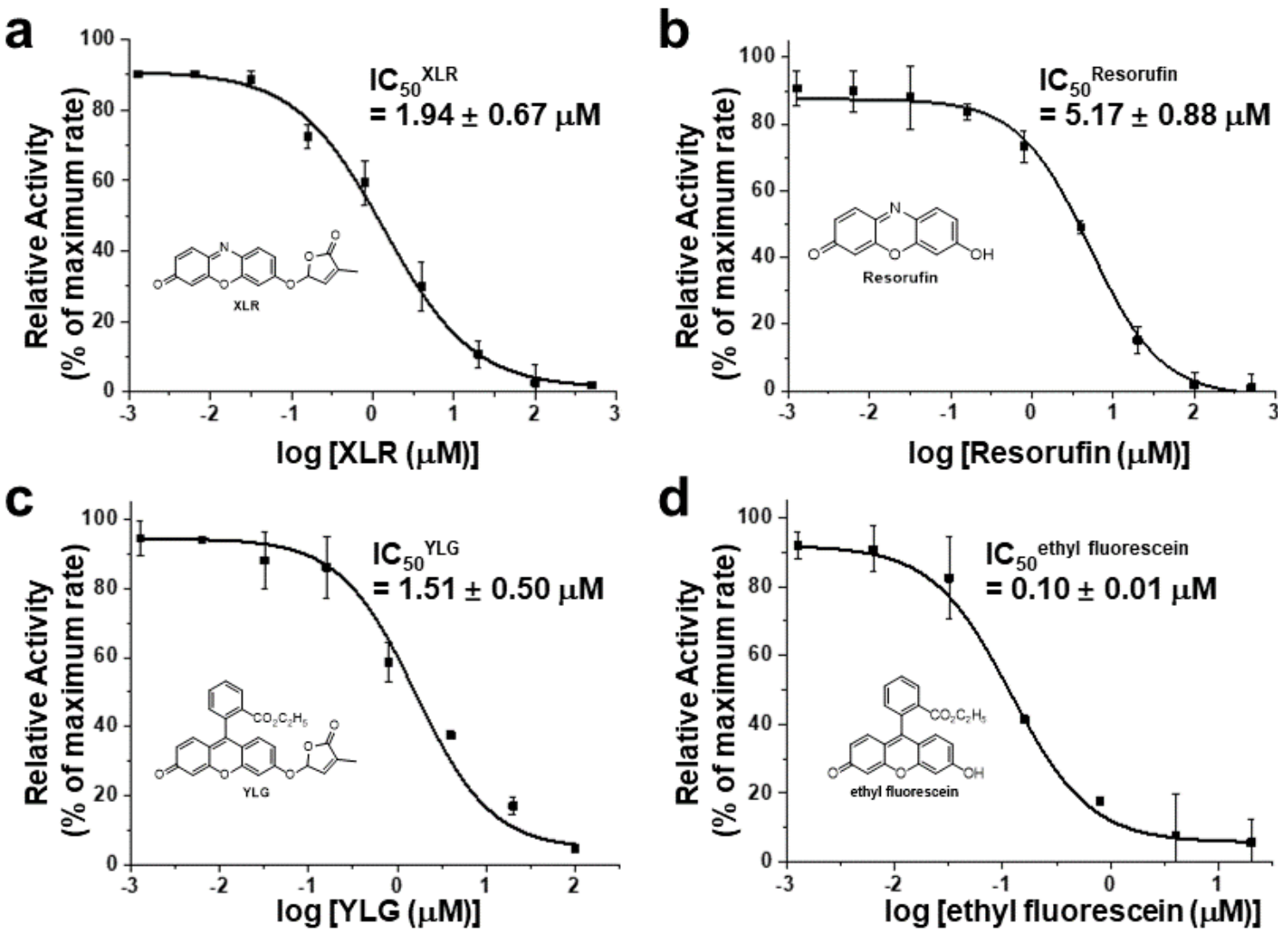

Figure S13. Competitive inhibition of ShHTL7-mediated YLG $(3 \mu \mathrm{M})$ hydrolysis by XLR (a) and resorufin (b), and XLR $(3 \mu \mathrm{M})$ hydrolysis by YLG $(\mathbf{c})$ and ethyl fluorescein $(\mathbf{d})$. Error bar indicates $\mathrm{SD}, \mathrm{n}=3$. 

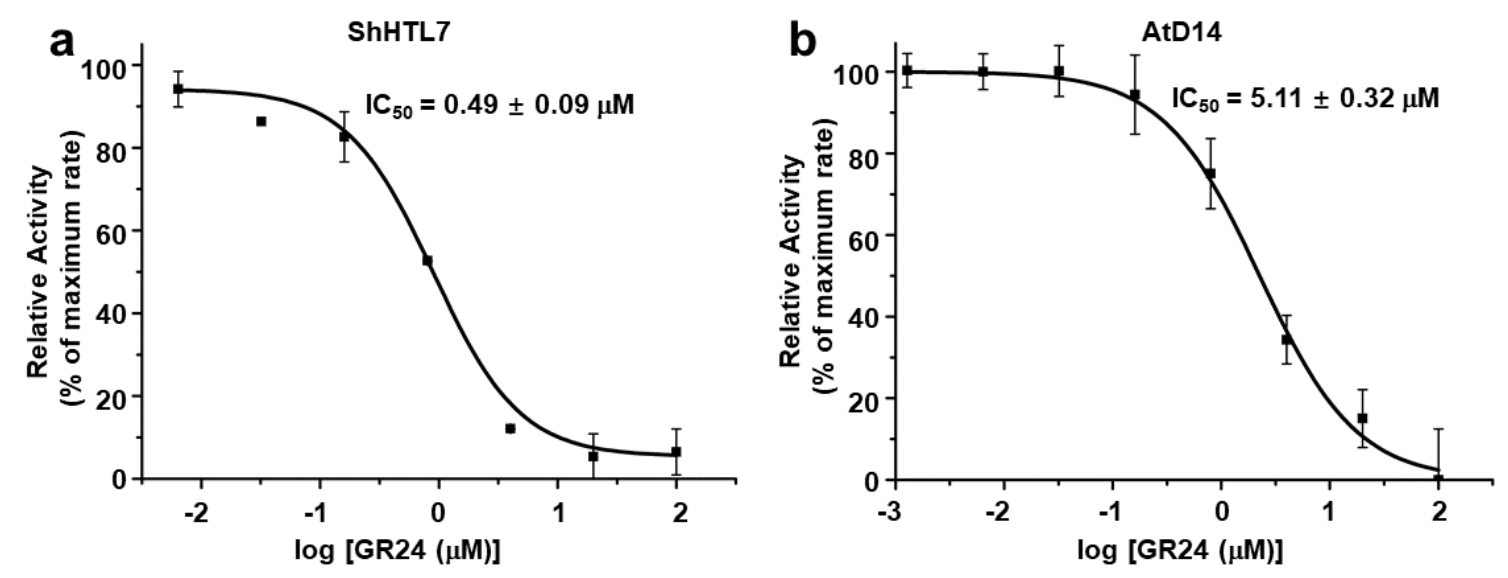

Figure S14. Competitive inhibition of ShHTL7 (a) and ShD14 (b) mediated YLG hydrolysis by GR24. Error bar indicates SD, $\mathrm{n}=3$.
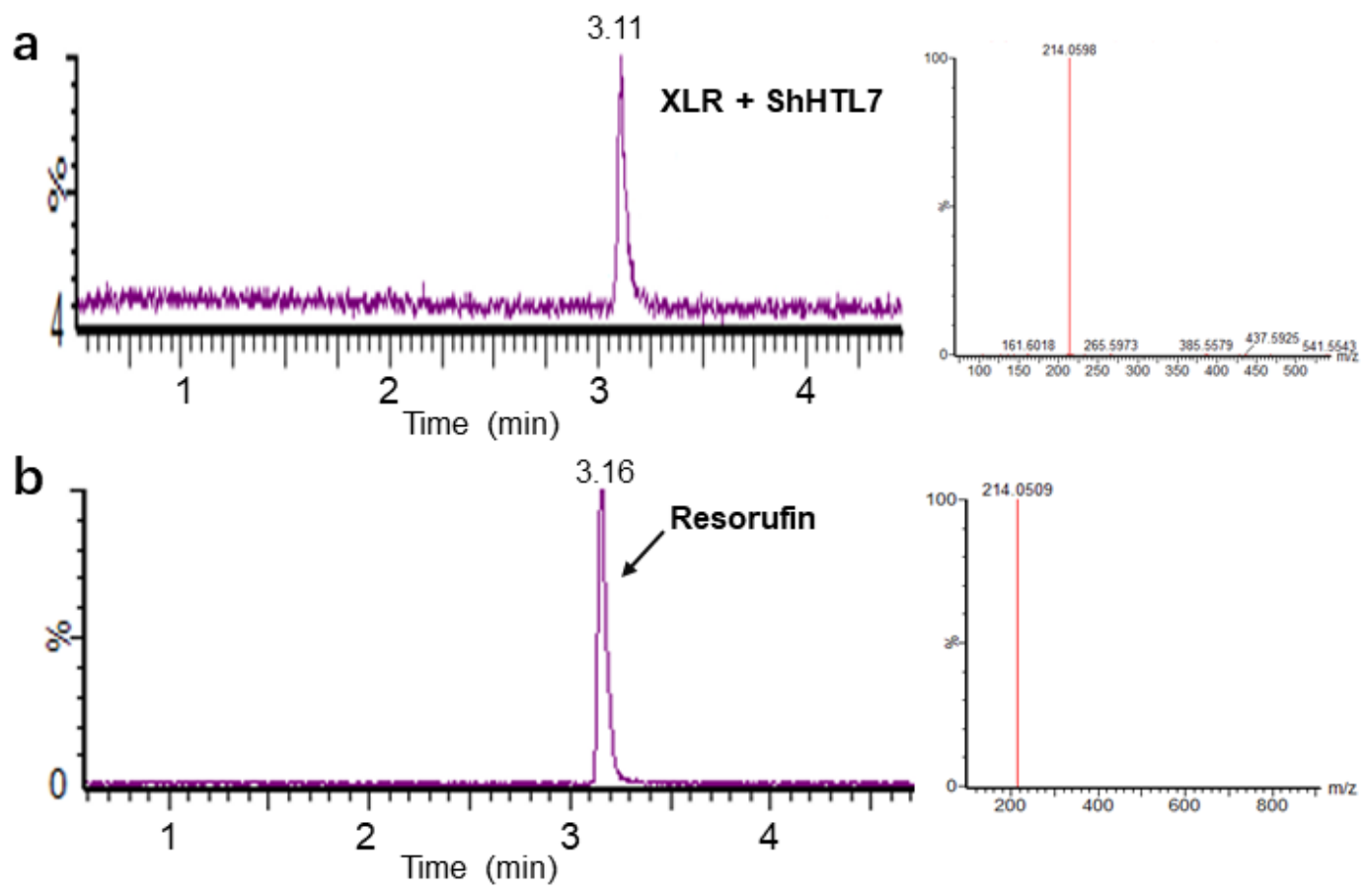

Figure S15. UPLC-HRMS analysis of the XLR-ShHTL7 (a) and resorufin (b) in the reaction system. 


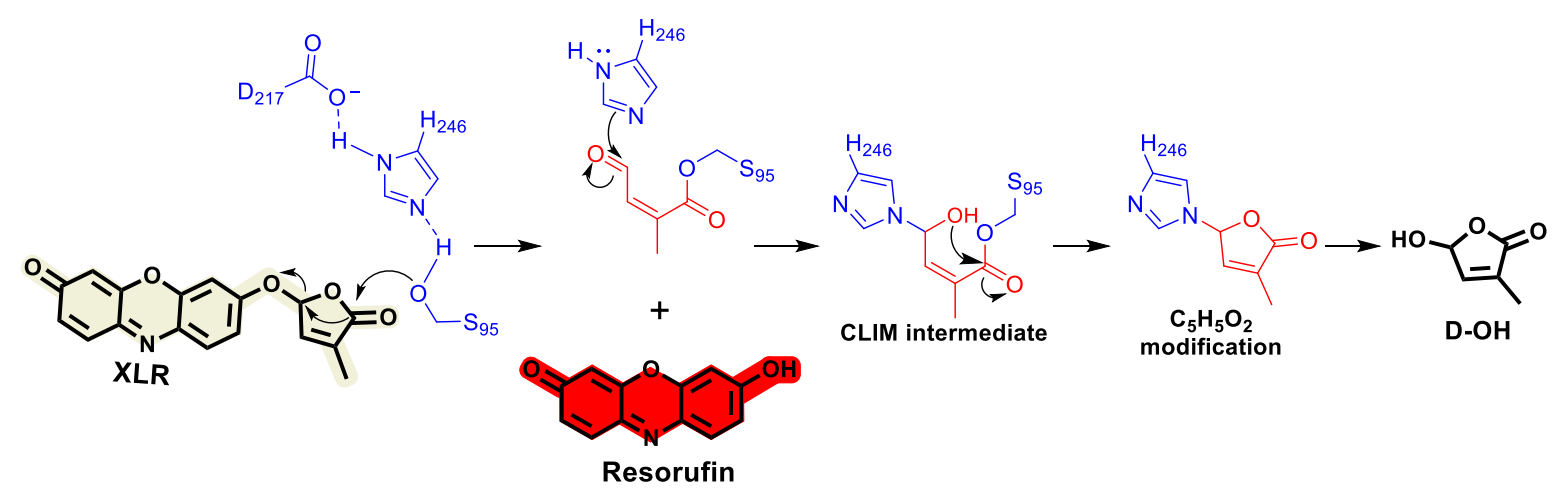

Figure S16. A proposed schematic diagram of ShHTL7-mediated XLR hydrolysis.
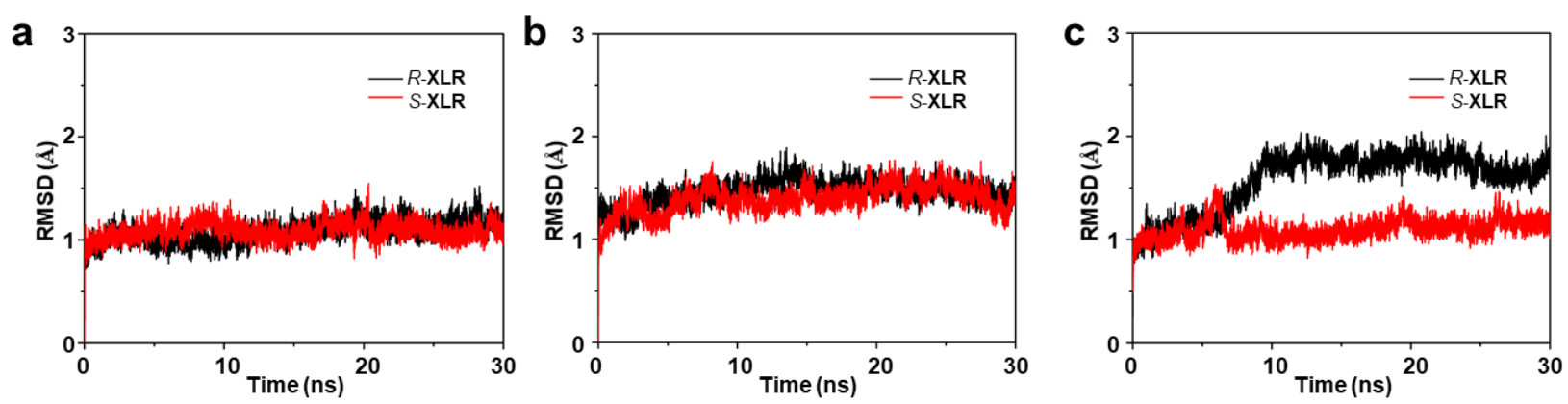

Figure S17. The RMSD of the N, CA, C atoms of $(R, S)$-XLR with respect to the starting structure of ShHTL7 (a), AtD14 (b), and ShD14 (c). The RMSDs of heavy atoms of the (R)-XLR-SL receptor with respect to the starting conformation are shown in black lines. The RMSDs of heavy atoms of the $(\boldsymbol{S})$-XLR-SL receptor with respect to the starting conformation are shown in red lines. 

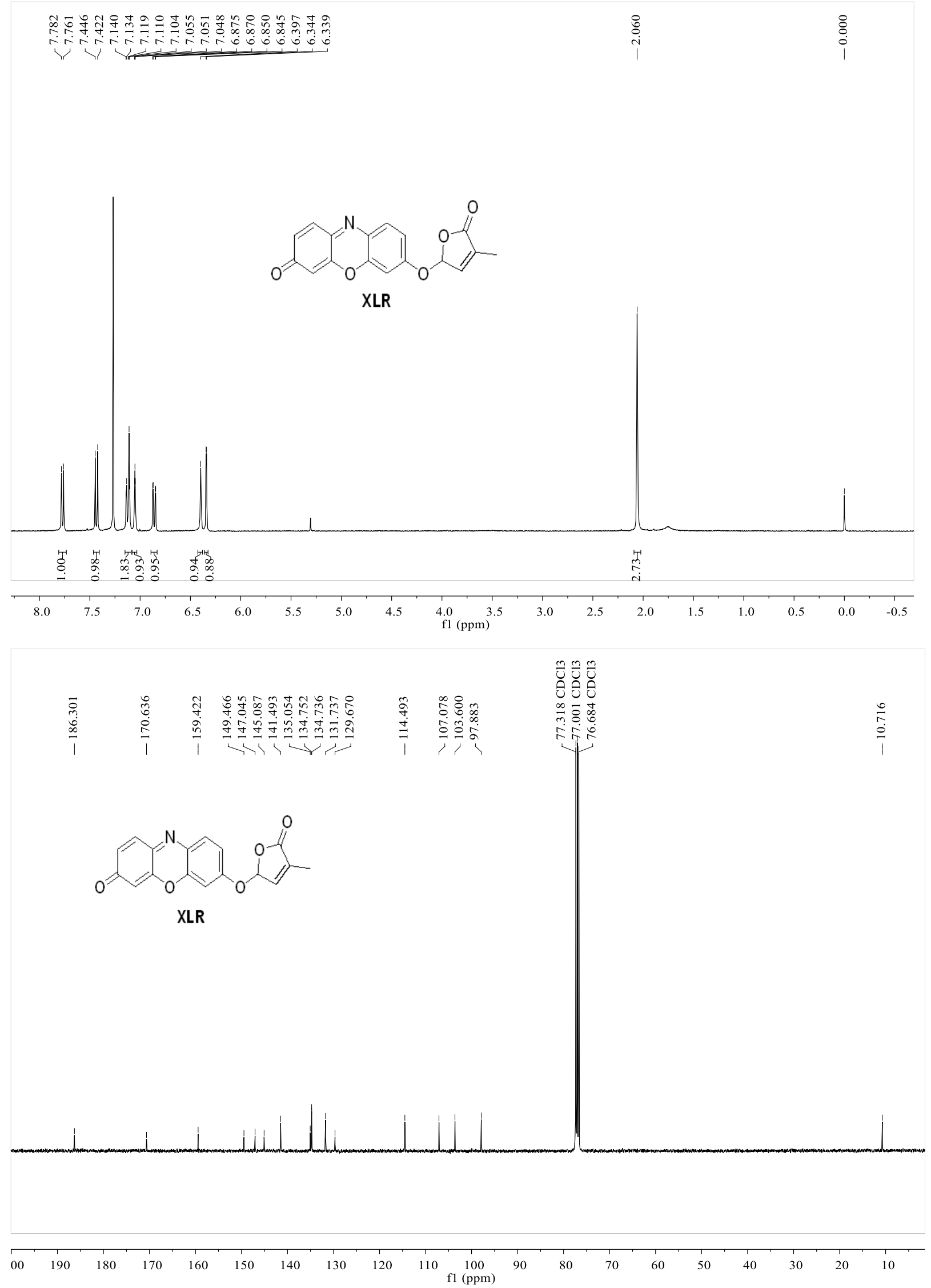
larian QFT-ESI
ile: Wdw1 161_ESI.trans

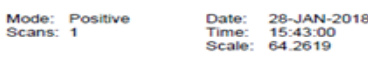

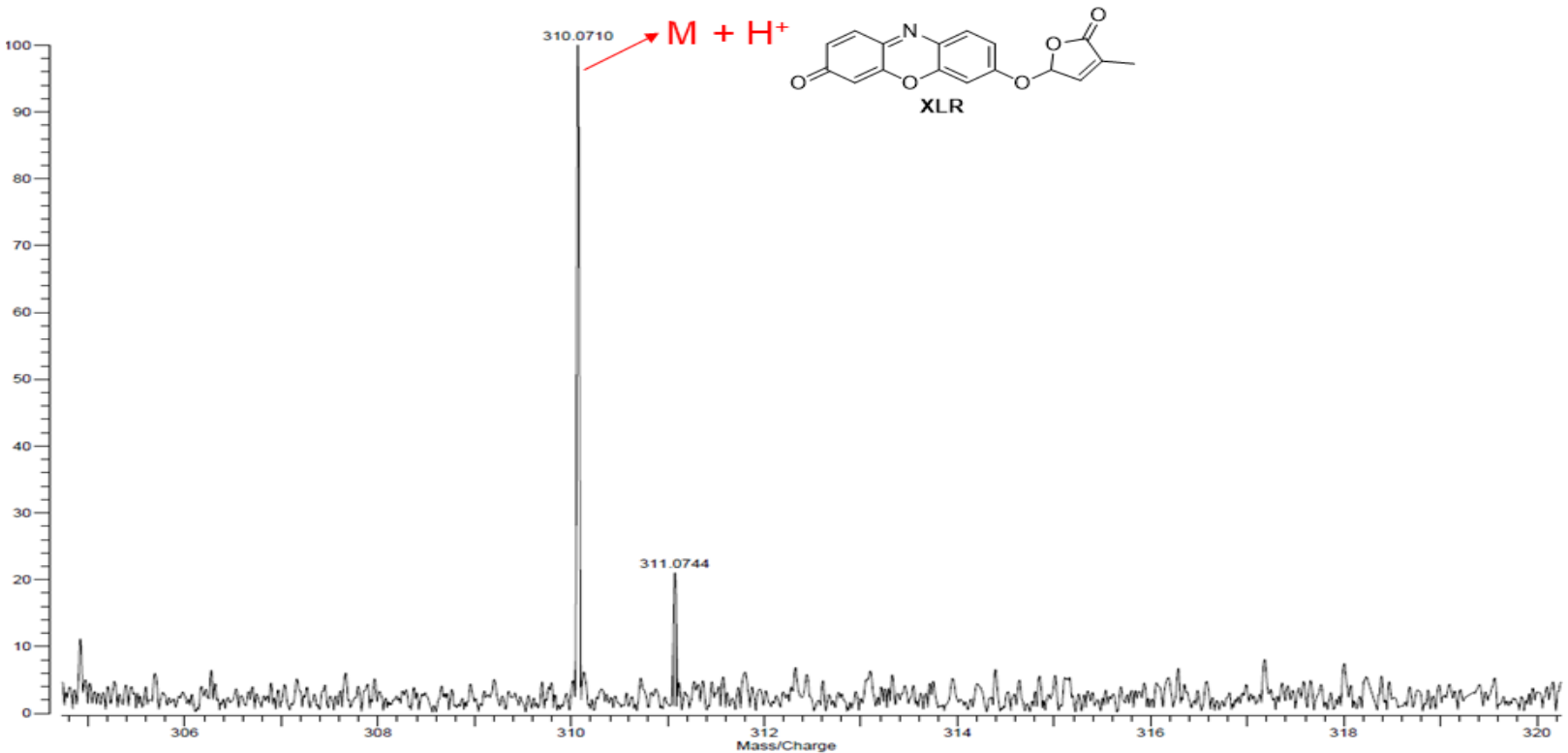




\section{Supporting references}

(1) Tsuchiya, Y.; Yoshimura, M.; Sato, Y.; Kuwata, K.; Toh, S.; Holbrook-Smith, D.; Zhang, H.; McCourt, P.; Itami, K.; Kinoshita, T., Probing strigolactone receptors in Striga hermonthica with fluorescence. Science 2015, 349, 864-868.

(2) Lachia, M. D.; De Mesmaeker, A.; Villedieu-Percheron, E.; Wolf, H. C.; Jung, P. J. M.; Lanfermeijer, F. C.; Van Den Wijngaard, P. W. J.; Screpanti, C. Strigolactam derivatives as plant growth regulating compounds. US 09210929, US patent, 2015.

(3) Lombardi, C.; Artuso, E.; Grandi, E.; Lolli, M.; Spirakys, F.; Priola, E.; Prandi, C., Recent advances in the synthesis of analogues of phytohormones strigolactones with ring-closing metathesis as a key step. Org. Biomol. Chem. 2017, 15, 8218-8231.

(4) Sun, Q.; Yang, S. H.; Wu, L.; Dong, Q. J.; Yang, W. C.; Yang, G. F., Detection of intracellular selenol-containing molecules using a fluorescent probe with near-zero background Signal. Anal. Chem. 2016, 88, 6084-6091.

(5) Ismail, I.; Wang, D.; Wang, Z.; Wang, D.; Zhang, C.; Yi, L.; Xi, Z., A julolidine-fused coumarin-NBD dyad for highly selective and sensitive detection of H2S in biological samples. Dyes Pigm. 2019, 163, 700-706.

(6) Bueno, C.; Villegas, M. L.; Bertolotti, S. G.; Previtali, C. M.; Neumann, M. G.; Encinas, M. V., The excited-state interaction of resazurin andresorufin with amines in aqueous solutions. photophysics and photochemical reaction. Photochem. Photobiol. 2002, 76, 385-390.

(7) de Saint Germain, A.; Clave, G.; Badet-Denisot, M. A.; Pillot, J. P.; Cornu, D.; Le Caer, J. P.; Burger, M.; Pelissier, F.; Retailleau, P.; Turnbull, C.; Bonhomme, S.; Chory, J.; Rameau, C.; Boyer, F. D., An histidine covalent receptor and butenolide complex mediates strigolactone perception. Nat. Chem. Biol. 2016, 12, 787-794.

(8) Waters, M. T.; Bussell, J. D.; Jost, R., Arabidopsis hydroponics and shoot branching assay. Bioprotocol 2012, 2, e264.

(9) Chen, J.; Xue, Q.; Ma, Y.; Chen, L.; Tan, X., Streptomyces pactum may control Phelipanche aegyptiaca in tomato. Appl. Soil Ecol. 2020, 146, 103369.

(10)Pouvreau, J. B.; Gaudin, Z.; Auger, B.; Lechat, M. M.; Gauthier, M.; Delavault, P.; Simier, P., A high-throughput seed germination assay for root parasitic plants. Plant methods 2013, 9, 32.

(11)Sun, Q.; Qiu, Y.; Chen, J.; Wu, F. S.; Luo, X. G.; Guo, Y. R.; Han, X. Y.; Wang, D. W., A colorimetric and fluorescence turn-on probe for the detection of palladium in aqueous solution and its application in vitro and in vivo. Spectrochim. Acta. A. Mol. Biomol. Spectrosc. 2020, 239, 118547. 
(12)Ma, C. W.; Ng, K. K.; Yam, B. H.; Ho, P. L.; Kao, R. Y.; Yang, D., Rapid broad spectrum detection of carbapenemases with a dual fluorogenic-colorimetric probe. J. Am. Chem. Soc. 2021, 143, 6886-6894.

(13)Shahul Hameed, U.; Haider, I.; Jamil, M.; Kountche, B. A.; Guo, X.; Zarban, R. A.; Kim, D.; Al-Babili, S.; Arold, S. T., Structural basis for specific inhibition of the highly sensitive ShHTL7 receptor. EMBO Rep. 2018, 19, e45619.

(14)Liu, H. W.; Chen, L.; Xu, C.; Li, Z.; Zhang, H.; Zhang, X. B.; Tan, W., Recent progresses in small-molecule enzymatic fluorescent probes for cancer imaging. Chem. Soc. Rev. 2018, 47, 7140-7180.

(15)Wu, X.; Shi, W.; Li, X.; Ma, H., Recognition moieties of small molecular fluorescent probes for bioimaging of dnzymes. Acc. Chem. Res. 2019, 52, 1892-1904.

(16)Li, H.; Kim, D.; Yao, Q.; Ge, H.; Chung, J.; Fan, J.; Wang, J.; Peng, X.; Yoon, J., Activitybased NIR enzyme fluorescent probes for the diagnosis of tumors and image-guided surgery. Angew. Chem. Int. Ed. Engl. 2020, https://doi.org/10.1002/ange.202009796.

(17)Guo, W. Y.; Fu, Y. X.; Liu, S. Y.; Mei, L. C.; Sun, Y.; Yin, J.; Yang, W. C.; Yang, G. F., Multienzyme-targeted fluorescent probe as a biosensing platform for broad detection of pesticide residues. Anal. Chem. 2021, 93, 7079-7085.

(18) Burger, M.; Chory, J., The many models of strigolactone signaling. Trends Plant Sci. 2020, $25,395-405$. 